\title{
Teachers' perceptions of school climate in inclusive schools
}

\author{
Weny Savitry Sembiring Pandia, ${ }^{1}$ Margaretha Purwanti ${ }^{2}$ \\ ${ }^{1,2}$ Faculty of Psychology, Universitas Katolik Indonesia Atma Jaya, Jakarta - Indonesia
}

\begin{abstract}
Teachers are important figures in forming the school climate, including in inclusive schools. Their perception will influence the learning process and indirectly affect students' achievements. This study aimed to identify teachers' perceptions of school climate in inclusive schools. Mixed method was used in this study. Quantitatively, questionnaires were given to 127 teachers from 2 inclusive vocational schools and 4 inclusive high schools in Jakarta, Bandung, and Surakarta, using accidental sampling technique. In each class, there were $2-3$ students with special needs, which encompassed different types of disability such as physically disabled, low vision, slow learner, Attention Deficit Hyperactivity Disorder (ADHD) and autism. Qualitatively, school observations and interviews were conducted with 10 teachers. The results showed that their perceptions of the school climate in high schools and vocational schools tended to be positive although the knowledge and application of inclusive education still needed to be improved. There were differences in several perceptual aspects due to the duration of teaching and the type of school.
\end{abstract}

Keywords: inclusive school; Senior High School; teacher's perception; Vocational School

\begin{abstract}
Abstrak: Guru merupakan tokoh penting untuk membentuk iklim sekolah, termasuk di sekolah inklusi. Persepsi guru akan memengaruhi pembelajaran dan secara tidak langsung berpengaruh terhadap prestasi belajar siswa. Penelitian ini bertujuan untuk mengidentifikasi persepsi guru terhadap sekolah inklusi. Metode campuran digunakan dalam penelitian ini. Secara kuantitatif, kuesioner diberikan pada 127 guru dari 2 SMK dan 4 SMA inklusi di Jakarta, Bandung, dan Surakarta, dengan teknik accidental sampling. Di setiap kelas, secara umum ada 2-3 siswa berkebutuhan khusus, dengan jenis yang bervariasi, misalnya: tunadaksa, penglihatan lemah, lambat belajar, Attention Deficit Hyperactivity Disorder (ADHD), dan autisme. Secara kualitatif, dilakukan observasi terhadap sekolah dan kelompok terhadap total 10 guru. Hasil penelitian menunjukkan bahwa persepsi guru terhadap iklim sekolah di SMA dan SMK cenderung positif, meski pengetahuan dan penerapan pendidikan inklusi masih perlu ditingkatkan lagi. Ada perbedaan pada beberapa aspek persepsi yang dipengaruhi oleh lama mengajar dan jenis sekolah.
\end{abstract}

Kata Kunci: sekolah inklusi; persepsi guru; SMA; SMK

Corresponding Author: Weny Savitry Sembiring Pandia (e-mail: weny.sembiring@atmajaya.ac.id). Faculty of Psychology, Universitas Katolik Indonesia Atma Jaya, Jl. Jend. Sudirman No. 51, Jakarta 12930. 


\section{Introduction}

Inclusive education is one of the policies from government to cope with education problem issue for students with special needs. Regulation of Indonesian Minister of National Education No. 70 year 2009 states that inclusive education is a system of providing education to provide opportunities for all students who have disabilities and potential intelligence and/or special talents to attend learning and education with general students in the same environment. This regulation requires the practice of inclusive education that prioritizes education for all where all students learn together, get good support, and differences in the child's self are recognized and valued (Kirk, Gallagher, Coleman, \& Anastasiow, 2012).

A positive school climate is needed in inclusive schools. A positive school climate can increase motivation (Zins, Weissberg, Wang, \& Walberg, 2004) and produce high academic achievement for all students, including students with special needs. School climate can prevent problem behaviors (Case, 2008; Dernowska, 2017) and promote healthy behavior in the school community (Dernowska, 2017). Further, about the importance of a positive school climate stated by Fraillon (2004, quoted from Na'imah dan Tanireja, 2017), that the welfare (well-being) students in schools cannot be separated from the school context, where the school climate is one of its constituents.

Dernowska (2017) state that school climate relates to a personal approach. It can be seen from the attitudes and behaviors portrayed by teachers, students, principals, and other individuals in the school. According to National School Climate Council (2013) school climate is a pattern in school life that reflects norms, goals, values, interpersonal relationships, teaching and learning practices, and organizational structure. School climate is the overall context of a school, which is related to how individual behavior contributes to collective feeling from all individuals in school.

Case (2008) state that based on authoritative discipline theory, a positive school climate is formed from the component responsiveness (social support), as the behavior of teachers or other adults in schools that are responsive to the social and emotional needs of children by showingwarmth, acceptance and care. This dimension consists of relationship aspects between students, student-teacher relations, respect for diversity, and teacher-parent communication. Another dimension is demandingness (structure), which is an expectation of clearly stated behavior, fair rules, consistent implementation of rules, and monitoring and directing of students' behavior as needed. Thus, this dimension consists of clarity of expectations, fair rules, security in schools, and student involvement in learning. Knowledge of these dimensions can be used to assess the needs of program development and program evaluation in schools.

School climate is related to perceptions about various issues at school, namely beliefs, values, and attitudes of students, teachers, administrative staff, parents, and the community. This perception of all school members is a component that forms the effective teaching of the teacher, the good achievements of students, and the active role of parents in the school. School climate is the biggest indicator of the effectiveness of a school. The factors of the school climate itself are subjective caused by the perceptions of a person (Freiberg \& Stein, 2005). Perception is a brain process that organizes and interprets sensory information (Wade \& Tavris, 2008). Perception is also defined as the result of a psychological process in which meaning, relationships, context, 
judgment, previous experience, and memory play a role. Furthermore, perception is influenced by experiences and ways of thinking, as well as moods or interests of each person so that perception is seen as subjective case. Hoy and Miskel (1996, quoted from Freiberg \& Stein, 2005) explained that perceptions of the school climate could influence the attitudes and behavior of members of the school community. If members of the school community have a positive perception of the school climate, then problems at school will be minimalized yet optimal learning outcomes will be achieved.

Although all elements of the school such as students, teachers, supporting staff, families, and the community, have contributed to the formation of the school climate. The principal and teachers are key figures that can shape a positive school climate. The principal plays an important role in the school leadership to design the goals and behaviors expected of the teacher and students, but it is the teacher who generally interacts directly with students. When teachers actively make changes, students will also change and a positive school climate can be achieved (Moran, Carlson, \& Tableman, 2012). In addition, Schunk, Pintrich, and Meece (2008) state that the leadership displayed by the teacher will affect the classroom climate and frther the school climate. In inclusive schools, according to Spektor-Levy and Yifrach (2017) teachers need to adapt on teaching techniques, evaluations, and many other things when they accept students with special needs in their class. The willingness to adapt is greatly influenced by the teacher's perception of the definition of "inclusion". This is in line with the statement Unianu (2012) that in inclusive schools, teachers' understanding of the terminology "inclusion" will show how the application of learning is carried out; between simply putting students together with regularstudents without modifying learning or restructuring the curriculum to accommodate student needs.

Although there are already government policies regarding inclusive education, the implementation of inclusive education in Indonesia and in other countries still needs to be improved. According to Irwanto, Kasim, Fransiska, Lusli, \& Okta (2010) various examples of problems found were about inadequate facilities and infrastructure, acceptance of less positive friends, teachers who did not understand the handling of students with special needs, and management of inclusive schools that still lacked of it. Despite positive attitude of teachers in structruringindividual programs for students with special needs, they still havenot had sufficient knowledge on this matter (Arta, 2018). Teachers also have not had deep understanding aboutstudents with special needs' characteristics, and also an understanding of design program, implementation, and evaluation of the program (Agustin \& Pandia, 2017). Further, there are still teachers witha negative attitude towards the implementation of inclusive schools and students with special needs (Triwulandari \& Pandia, 2015). Perceptions, attitudes, knowledge and self-efficacy teachers, support from school principals and school administrators, as well as training to prepare teachers also still face challenges in other countries (Chakraborti-Ghosh, Orellana, \& Jones, 2014; Dev \& Kumar, 2015; MacFarlane \&Woolfson, 2013; Song, 2016; Unianu, 2012). These things affect the teacher's perception of the school climate and the learning process stimulated by teachers in the classroom. Furthermore, Na'imah and Tanireja (2017) stated that the conducive climate experienced by students would improve the welfare (well-being) of students, and would further increase the optimal development and learning outcomes of students.

The school climate plays an important role in achieving educational goals. At the Senior High 
School (SMA) or Vocational High School (SMK) level, the school climate needs to be really addressed. SMA/SMK are the last level of formal education. After this level, students generally decide to continue their education to college or go straight into the world of work. Thus, every student, both regular and with special needs, needs to have a good readiness of knowledge and skills as a result of his learning in previous levels of education. Therefore, a study of the climate of inclusive schools at this level is very important to do, so that appropriate development programs can be made for school members, especially teachers.

This study aimed to see a picture of teachers' perceptions of inclusive school climate, both in high school and vocational school. Many challenges in the implementation of inclusive schools can make teachers have negative perceptions of inclusive school climate, although on the other hand the existence of support for the implementation of inclusive schools can also lead to more positive perceptions. The identification and mapping carried out from this study can be useful for the next intervention step. Suggestions for the development of an inclusive education model based on best practice that has been carried out by schools can be part of efforts to develop a positive inclusive school climate.

\section{Method}

This study was a quantitative and qualitative research using self-report method, interviews, and observations. The variable of this study was the teacher's perception of the inclusive school climate. The study was conducted in 6 inclusive schools, namely 2 Vocational High Schools (SMK) and 4 High Schools (SMA) in Jakarta, Bandung and Surakarta. The selection of these three cities was because DKI Jakarta had declared itself to be an inclusive province with the Governor Regulation No. 116 of 2007, as well as Surakarta with Regional Regulation No. 4 of 2010. In addition, Bandung was a place where the national declaration on inclusive education in Indonesia was announced through the Indonesian National Declaration on August 8-14, 2004. These three cities were expected to be an example of the model of implementing inclusive education in Indonesia. However, based on research that had been done, in practice there were still things that need to be improved from the implementation of inclusive education so that the initial excavation of the practice of inclusive education in these three cities was considered appropriate. The study was conducted in inclusive high schools/vocational high schools, namely high schools/vocational schools appointed by the government and private sector, where students with special needs sit in one class together with regular students. High school/vocational school in question are: SMAN A Jakarta, SMKN B Jakarta, Private SMA C Bandung, Private SMAD Bandung, Private SMA E Surakarta, and SMKF Surakarta. The sample selection was done accidentally. Questionaires were distributed to 127 teachers. Besides, group interviews were conducted to10 teachers and observation of the environment was hwld in each school.

Quantitative measuring instrument used was the adaptation of Perception of School Climate Inventory (Case, 2008). The trial was conducted on 75 teachers. Obtained reliability value $=$ 0.934 . Statements that were considered valid were those that had a correlation with the total subscale score and the total scale above 0.329 based on the formula Pearson's Product Moment. There were 2 parts in this measuring instrument, Part I (School Climate Survey) consists of 54 items representing of 10 subscales, namely: teacher-student relations, student-student 
relations, respect for diversity, school-wide student engagement, clarity of expectation, fairness of rules, school safety, school-wide bullying, teacher-home communications, and staff relations. Part II (Teaching Technique) consists of 14 items representing 3 subscales, namely use of positive behavior technique, use of punitive technique, and social emotional learning technique. There were five choices of answers, namely Strongly Agree, Agree, Neutral, Disagree, and Strongly Disagree. Data were analyzed using descriptive statistical techniques. From the average score, a middle value was determined in the range of minimum and maximum scores that could be achieved in each subscale. The average score above the middle value indicates perceptions that tended to be positive for school climate, while the average scores below the mean indicated perceptions that tend to be negative for school climate.

The interview guide was compiled based on dimensions and aspects of the school climate of National School Climate Center (National School Climate Council, 2013) which consisted of an open physical environment and conducive to learning, a social environment that included communication and interaction between school members, an effective school environment that creates sense of belonging, as well as self-esteem, as well as an academic environment that supports learning and self-fulfillment. Content analysis was performed on verbatim data from interviews.

The observation guide was made based on the criteria for the inclusion school aspects of Center for Studies Inclusive Education (Thomas, Walker, \& Webb, 1998) namely physical and non-physical accessibility, comparison of teaching situations in the classroom, and completeness of school support. Summary of the results of observations were used to strengthen the data from interviews and questionnaires.

\section{Results}

In the following section, the results of the research were obtained quantitatively and qualitatively. Demographic data of research subjects as in Table 1.

Based on Table 1, it could be seen that most of the teachers who became research respondents were female. The length of teaching teacher was many varies, the most was under five years, although there were quite a number of teachers who did not mention the length of teaching. In terms of age, respondents were mostly in the 41-45 years age group, although the number was almost the same as the number of respondents who did not fill in the age column.

The following wasa quantitative description of the results of research, namely teacher perceptions of the school climate obtained from the five schools. Teacher perceptions of the school climate can be seen in Table 2.

Based on Table 2, it showedthat teachers generally had perceptions that tend to be positive towards the school climate subscale. The highest score was in the teacher-home communication subscale ( $M=21.12$, $\operatorname{Min}=4$, Max $=25)$, means the teacher perceived communication between teacher and parent, and wanted to work with parents to solve problems in children was best compared to other aspects. Other subscales that were classified as good were respect to diversity $(M=20.98$, Min $=14$, Max $=25)$, staff relations $(\mathrm{M}=20.59$, Min $=0$, Max $=25)$, and used of the technique Social Emotional Learning ( $M=20.43$, $\operatorname{Min}=0$, Max $=25$ ). 
Table 1.

Teacher Demographic Data $(\mathrm{N}=127)$

\begin{tabular}{|c|c|c|c|c|c|c|c|c|}
\hline $\begin{array}{c}\text { Sex } \\
\text { (Gender) }\end{array}$ & $\mathrm{N}$ & $\begin{array}{c}\text { Percentage } \\
\text { (\%) }\end{array}$ & $\begin{array}{c}\text { Age } \\
\text { (years) }\end{array}$ & $\mathrm{N}$ & $\begin{array}{c}\text { Percentag } \\
\text { e (\%) }\end{array}$ & $\begin{array}{c}\text { Teaching } \\
\text { duration } \\
\text { (years) }\end{array}$ & $\mathrm{N}$ & $\begin{array}{c}\text { Percentage } \\
\text { (\%) }\end{array}$ \\
\hline Male & 23 & 18.11 & $\leq 30$ & 27 & 21.26 & $\leq 5$ & 35 & 27.56 \\
\hline Female & 53 & 41.73 & $31-40$ & 24 & 18.90 & 1.14 & 19 & 14.96 \\
\hline \multirow[t]{5}{*}{$\mathrm{n} / \mathrm{a}$} & 51 & 40.16 & $41-50$ & 28 & 22.05 & $11-15$ & 7 & 5.51 \\
\hline & & & $>50$ & 19 & 14.96 & $16-20$ & 14 & 11.02 \\
\hline & & & $\mathrm{n} / \mathrm{a}$ & 29 & 22.83 & $21-25$ & 5 & 3.94 \\
\hline & & & & & & $>25$ & 19 & 14.96 \\
\hline & & & & & & $n / a$ & 28 & 22.05 \\
\hline Total & 127 & & & 127 & & & 127 & \\
\hline
\end{tabular}

Table 2.

Perception of School Climate $(\mathrm{N}=127)$

\begin{tabular}{lcccc}
\hline \multicolumn{1}{c}{ Subscale } & Mean & SD & Min & Max \\
\hline Teacher-student rel & 19.01 & 3.37 & 10 & 25 \\
Student rails & 16.20 & 2.37 & 8 & 20 \\
Resp for diversity & 20.98 & 2.60 & 2. & $>25$ \\
Std engagement & 19.46 & 2.95 & $>10$ & $>25$ \\
Clarity of expect. & 16.15 & 2.28 & 5 & $>20$ \\
Fairness of rules & 16.27 & 2.45 & 4 & $>20$ \\
School safety & 19.06 & 2.87 & $>11$ & $>24$ \\
Bullying & 22.71 & 4.10 & 6 & $>29$ \\
Teacher-home com & 21.12 & 2.82 & 4 & $>25$ \\
Staff relation & 20.59 & 3.20 & 0 & $>25$ \\
Positive behavior & 15.97 & 2.57 & 0 & $>20$ \\
Punitive technique & 11.44 & 2.78 & 0 & $>17$ \\
SEL Technique & 20.43 & 2.89 & 0 & $>25$ \\
\hline
\end{tabular}

The teacher perceived that respects differences in students had displayed, and students also had sufficient behavior to show respect for each other despite differences. The teacher also perceived good relations and cooperation between staff in the school. The social emotional approach in the perception of teaching techniques had been used, thus the teacher perceived that they had encouraged students to take responsibility in following learning in school.

For the school-wide bullying subscale, teachers' perceptions tended to be negative ( $M=$ 22.71, $\operatorname{Min}=6$, Max = 29). This means that teachers tended not to perceive harassment in schools. However, from the interviews it was found that the teacher himself doubted this, because harassment could have occurred without the teacher's knowledge.

This study also looked at differences in perceptions between high school and vocational school teachers. By using the analysis of t-test, the results showed that between high school and vocational high school teachers showed significant differences in perception scores on the school climate $(234.75<249.79)$ i.e on the dimensions of teacher-student relations ( $\mathrm{t}(125)$ $=-5,401, \mathrm{p}<.005)$ where vocational teacher scored were higher than high school teacher 
scores $(18.05<21.18)$, school-wide student engagement $(\mathrm{t}(125)=-1.985, \mathrm{p}<.005)$ where the score of SMK teachers was higher than high school teachers $(19.11<20.23)$, clarity of expectations ( $\mathrm{t}(125)=-2.148, \mathrm{p}<.005)$ where the score SMK teachers were higher than high school teachers (1839 15.86<16.79), fairness of rules $(\mathrm{t}(125)=-2.190, \mathrm{p}<.005)$ where the score of the SMK teacher was higher than high school teacher $(15.95<16.97)$, school safety $(\mathrm{t}(125)=$ $3.091, \mathrm{p}<.005)$ where the vocational teacher score was higher than the high school teacher $(18.55<20.21)$, and staff relations ( $t$ 1,188 (125) $=-2,699, \mathrm{p}<.005)$. Based on the results of the analysis, it could be concluded that vocational teachers had more positive perceptions of the school climate compared to high school teachers in terms of the relationship between teachers and students, student involvement in learning, clarity of expectations of things students must fulfill, fairness of rules in school, security at school, and relations between staff at school.

There was no significant difference between high school and vocational school teachers on the subscale: student-student relation $(\mathrm{t}(125)=$ $-1.734, \mathrm{p}>.005)$, respect for diversity $(\mathrm{t}(125)=$ $-1,078, p>.005)$, school-wide bullying ( $\mathrm{t}(125)=$ $-1,616, \mathrm{p}>$.005), teacher-home communications ( $\mathrm{t}$ $(125)=-.365, p>.005)$, use of positive behavior techniques $(t$ (125) $=-1.747, p>.005)$, use of punitive techniques ( $\mathrm{t}(125)=-1.747, \mathrm{p}>.005)$, use of punitive techniques ( $t(125) 125)=-1,864$, $\mathrm{p}>.005$ ), and use of Social Emotional Learning techniques $(t(125)=-1.628, p>.005)$.

Based on the length of teaching, there was a significant difference in the perception of the overall school climate and in the subscale student relationships, staff relations, and clarity of expectation between teachers with less than 5 years of teaching and teachers who taught more than 25 years. It could be seen that teachers who had taught more than 25 years have a more positive perception of the school climate in the aspects of relations between students, between staff, and clarity of expectations of the thing students must fulfill in learning.

Qualitatively, the following results were interviews obtained from teachers in each school. Interviews were conducted both individually and in groups ( 2 teachers per group):

\section{SMAN A in Jakarta}

SMAN A Jakartalocated on the edge of the highway with a beautiful school atmosphere. There are a lot of plants in the school, so the atmosphere feels shady and cool. The three-story school building and the Counseling (BK) teacher's room were located on the $2^{\text {nd }}$ floor with stairs that had no handles. This was quite difficult for the physically challenged or blind students who wanted to visit the counseling room. Though these students often visit the BK room to consult or just fill in spare time. Since it was declared a school that accepts students with special needs, the school had not provided special services in daily learning. Teaching was done in general like learning for regular students, and students with special needs were expected to follow as much as they could. It was only when the mid-term test and final test questions for students with special needs were made different. The teacher did not understand how to deal with students with special needs. Indeed, at the beginning there was briefing related to inclusive schools, but now the training and directives have never been given again by the government. Actually, Counseling (BK) teacher was the one who handled students with special needs, other teachers only taughtand paid attention to certain limits. The teacher did not use special learning aids and did not know that these tools exist, even though they were available at school. The teacher believed that students with special needs who find it difficult to 
follow learning in public schools should go to SLB because they were not optimal in absorbing subject matter. The teacher hoped that parents gave more special attention to the school, so that the teacher could more remember of the children with special needs.

\section{SMKN B in Jakarta}

The school was on a fairly busy side street, even though the road was not too big. Access to school by public transportation was quite easy. This school had been appointed as an inclusive school for several years to accept students with special needs.

In general, students with special needs chose majors that they were quite capable of attending, for example the Department of Culinary Arts. At school, teachers tried to understand students with special needs by giving special assessments to them, adjusting rules for students to follow, and during exams providing specific questions students could work on. The teacher showed sufficient understanding of the differences between inclusive and regular schools, and tried to understand the condition of students. The teacher tried to reprimand regular students who disturbed students with special needs so that these students rarely get negative treatment. However, in reprimanding students, teachers often say: "Do you want to be like ABK students (children with special needs)?" so that it is possible that there is an incorrect understanding of students with special needs in regular students. Students with special needs who were still having difficulty adjusting were facilitated by letting them do the things they want, such as sleeping at school, but were still given direction so they could adjust later. Parents were also asked to accompany children who wee still difficult to adjust.

The teachers had received training at the beginning of the appointment of the school as an inclusive school, but now there was no more training. There were no learning aids for students with special needs, and the teacher never tried to use special learning aids for these students. The teacher hopes that parents work more intensively with the school. The government is also expected to pay more attention to the existence of students with special needs.

\section{Private SMA C in Bandung}

The school was located in an area quite far from the highway. When entering the school environment, the school atmosphere was beautiful, 'warm', and friendly. When the children arrive, the teacher greets the child at the school gate. Students with special needs who come by bicycle are taught how to use bicycle standards and were given instructions on where to place their bicycles.

It seemed that the teacher had understood the concept of inclusion, but the teacher himself still did not feel that he has run the program to the maximum because there were still many things that must be pursued. Supporting facilities for students with special needs were quite a lot, such as assistant teachers, orthopedagogue, psychologists, and BK teachers. In class, teachers often used learning aids so that students with special or regular needs more easily understand the lesson. The main purpose of the teacher was to make children learn happily. There were special programs for students with special needs, and regular students could choose various extracurricular and intracurricular programs that suit to their interests. For students who were unable to participate in the learning provided a companion teacher, but if the student was able to participate in learning independently, then he was not accompanied. School rules were implemented consistently, including for students with special needs. The teacher could easily monitor the consistency of the rules because 
there were not too many students (only about 17 children and 2 parallel classes at each level).

All teachers at this school received guidance in preparation for handling students with special needs for one year before being appointed as permanent teachers, from identifying students' special needs to creating and implementing individual learning programs for students with special needs. If it was felt that teaching skills were inadequate, the teacher was assigned as a teacher's assistant. After being appointed as a permanent teacher, refreshment regarding the handling of children with special needs continued to be done in the form of training and seminars, which were generally given twice a year. The teacher hoped that facilities for inclusion students and training related to inclusion be improved.

\section{Private SMA D in Bandung}

The school was located on a fairly busy side street, and looks crowded because middle and high school student study in the same place. The location of the school was also one with the location of the lecture. The school was building construction, so the atmosphere was crowded and somewhat chaotic. Classrooms seemed cramped and dirty.

The teacher actually understands the concept of inclusion, but had not run the concept of inclusion optimally. This school was a public school that accepts children with special needs, without a special program due to teacher limitations. A few years ago, there was an officer helper, but now there were no more.

School rules were distinguished between students with special needs and regular students. Assessment of learning outcomes was also distinguished. Learning was done equally between students with special needs and regular students due to limited teacher knowledge, but for slow learner to learn a certain material emphasis. Regular students seemed to be able to accept the existence of students with special needs. For students with special needs, there were friends who were appointed by the teacher to assist these students while in school. The teacher hopes that students with special needs were given special assistance and special ways of teaching.

\section{Private SMA E in Surakarta}

The location of the school was located in a fairly large alley. The school area was quite large, with lots of trees which added to the beautiful atmosphere. At some point the yard area looks like a hut used by students to do creativity activities. In some places there appears to be sloping access which could be used for students who used wheelchairs. Students with special needs could be accepted at this school on condition that there was still a quota available, there was good intention from parents to work with the school, and the conditions of students were suitable for attending an inclusive school. An assessment of the admission of new students would be carried out to identify the abilities and special needs of students in learning.

For students with special needs who need it, there were foster teachers on duty as escorts. The task of foster teachers was to explore the psychological potential and condition of children. For each child, there was a foster teacher in charge of caring for children for at least 3 years so that the foster teacher was more familiar with the character of the child. Foster teachers had a variety of programs for foster children. In addition to foster teachers there were accompanying teachers. Assistance teachers receive training at least once a year, for example on how to handle students with special needs.

\section{SMKN F in Surakarta}

The school was located on the edge of a busy highway with a large yard. When entering the 
inside of the school, feels a comfortable and beautiful atmosphere. There were benches where students sit or guests who visit in the front of the school corridor. There was a garden with a fountain that added to the beautiful atmosphere of the front of the school. Various students' work was displayed in the showcase. In addition, there were also posters that display a list of student achievements and various activities that would take place. However, there did not appear to be any special accessibility for persons with disabilities, for example ramp/ incline. In this school there were no deaf students, but there were students with low vision and deaf. The requirement for schools when accepting new students was that students did not have physical disabilities that could interfere with learning. For students with special needs there were different treatments given. For example, for student low vision, during theoretical lessons he would sit in the front. When learning took place there were other students who are appointed to be assistants and there are teachers who are facilitators who accompany students. Practice exams were carried out individually. Teachers receive training on students with special needs from $\mathrm{BK}$ teachers.

From observations and interviews it could be seen that each school had a different environment. Some have looked at the needs of all students including students with special needs, some had not. There were differences that were apparent in private and public schools. In general, private schools provided more opportunities for teachers to attend various training or seminars and provide more adequate facilities. In addition, private schools usually better prepare regular students to accept the presence of students with special needs at school. There were schools where the teachers have understood the concept of inclusion and the teachers have received special training, but some have not yet understood. Handling and rules that apply to students including those with special needs differ in each school.

\section{Discussion}

This study showed that the model of implementing inclusive schools represented by the regions of Jakarta, Bandung and Surakarta varies greatly. There was no definitive model for the operation of inclusive schools in Indonesia. Each school seeks to develop its model according to the situation and conditions encountered. The school climates which tends to be perceived positively by the teacher shows that the teacher had perceived a balance between the disciplinary aspects carried out at the school and social support provided by both teachers and between students. Thus, students should be able to learn well in school, feel positive things in class and at school, and have good motivation and effort to learn (Case, 2008). With the perception of a positive school climate, teachers and students were sensitive to each other's social and emotional needs. Discipline was considered to have been run well by all school residents. With a positive school climate, discipline could run well because of the clearly stated rules and the expected behavior dissemination to all school members. Various rules had been obeyed, and monitoring of the implementation of the rules was always done (Moran et al., 2012). However, the results of this study indicated that teachers need to be aware of the harassment of students both regular students and those with special needs. Teachers were not convinced that schools were truly free from harassment. Thus, a system aimed at preventing and overcoming the problem of harassment needed to be had. 
Even though quantitatively the teacher's perception of the climate of inclusive schools looks positive in all schools, but qualitatively it appeared that in schools that are respondents to the research there are several problems that arise. The teacher feels a certain burden with the presence of students with special needs in school. This is because the teacher does not understand what to do with students so they feel confused in handling students in the class. Learning was felt to be not optimal with the presence of students with special needs. Every time the teacher had to repeat the material but students with special needs were still difficult to understand the material provided. When evaluations were conducted, the teacher also feels confused because the assessment must be modified so that students can continue to grade. Students with special needs are considered more suitable for attending special schools (Sekolah Luar Biasa/SLB). From this it appears that teachers do not fully understand the practice of learning in inclusive schools and the principle of education for all.

Although there were complaints from the teachers, the perception of the school climate that looked positive was suspected because in some schools the problem of students with special needs and learning systems in inclusive schools was only the responsibility of certain groups, for example Guidance and Conseling (BK) teachers or Deputy Principals for Curriculum. Other guesses that were supported by the results of qualitative data, in the end learning in class was done without considering fully the existence of students with special needs. That is, daily learning was done in general according to the ability of regular students only. If there were students with special needs who did not understand the material, the teacher would do certain things, for example repeating lessons specifically for these students outside class hours, lowering the assessment standards, or sending students with special needs to BK teachers. In state schools there were accompanying teachers who help with the making of final semester exam questions for students with special needs, but these assistant teachers were in charge of several inclusive schools. Thus, the services provided were less than optimal due to lack of manpower and time.

The interview results showed that at the beginning of the appointment as an inclusive school, the government held training for teachers and principals. However, the training was felt to be inadequate to make teachers have a positive enough knowledge and belief in 0669 in organizing inclusive schools. The school considers the need for special assistance and monitoring and evaluation from relevant agencies, so that the school can implement the inclusive education system appropriately. Actually, every year the government routinely conducts training on students with special needs and the practice of implementing inclusive schools. However, those who take part in training are usually headmaster or certain teachers who were indeed assigned to handle students with special needs. Schunk et al. (2008) and Sider, Maich, and Morvan (2017) explained that school principals had a major role in determining the climate of a school. Thus, the principal's participation in the training will actually make the climate of the school he leads more positive. The principal can develop a positive school culture and support teachers in implementing the principles of proper inclusive school administration. However, related to the training activities that have been taken sharing or transfer of knowledge often not done. This resulted in other teachers who did not attend the training not feel any self-improvement through 
trainings that have been held by the government. This is especially true in state schools. Whereas from the results of the research Song (2016), training for teachers was a very necessary because it will largely determine the positive attitude and self-efficacy of teachers. Teachers need to have creativity in teaching in order to facilitate all students including students with special needs in the class (Sellman, 2012), and can actually be obtained through various training to develop themselves. Teacher's experience, age, and professional qualifications greatly influence the things teachers will do in class (Deku \& Irene, 2017; Song, 2016). It was shown from the research data. Teachers who have longer teaching experience, more mature age, and have better qualifications as a teacher will be more creative in finding various teaching methods that are right for each student.

The teacher's attitude is crucial to the implementation of education for all and positive behavior towards students with special needs (Avramidis, 2013; Choate, 2004; MacFarlane \& Woolfson, 2013; Moran et al., 2012; Song, 2016). If the teacher had a positive perception of a group of students, especially students with special needs, the teacher would have difficulty implementing the principle of education for all.

For SMA C in Bandung, the teacher tried to foster the pleasure of learning for students by using a variety of programs and activities, there is a habit of warmth and courtesy, and a sense of security in expressing themselves. It is rarely found in other schools. According to Dernowska (2017), and Schunk et al. (2008) these are things that support the existence of a positive climate in schools. The physical environment of the school also supported the perception of a positive school climate. If the physical environment feels comfortable, the perception of a positive school climate would be more felt by the school community.
Vocational teachers had a more positive perception of the school climate than high school teachers, especially in terms of relationships between students. Whether this was related to learning activities in vocational high schools which have many practical activities or whether there are specific cultural elements of the region, still need to be further investigated.

Although the inclusive school climate has been perceived positively, there are still things that need to be improved in the implementation of inclusive schools. The intervention of teachers in inclusive schools still needs to be done by providing training to teachers and principals so that they have a positive attitude, good knowledge, and adequate creativity to accommodate the needs of all students (Sider et al., 2017; Song, 2016). Related to the improvement of teaching strategies for teachers, the making of the correct Individual Learning Programs by paying attention to the response to intervention, as well as involving parents in learning plans and making programs for students with special needs is very much needed (Friend \& Bursuck, 2015; Taylor, Smiley, \& Richard, 2009; Vaughn, Bos, \& Schumm, 2011). One important indicator of a positive school climate is well-being which is good from students. Therefore, students' perceptions of a positive school climate can be explored through well-being (Na'imah \& Tanireja, 2017). It needs a further investigated.

\section{Conclusion}

From the results of the research that had been done, it could be seen that each school has a different inclusion implementation model, with different types of special needs of students (for example: low vision, deaf, deaf, autism, ADHD, and slow learner). Teachers' perceptions of the school climate look positive, although from qualitative results there were still teachers who 
had negative perceptions of the existence of students with special needs. A number of these teachers still think that it is better for students with special needs to attend the special schools (SLB) only, or that handling the student with special needed (ABK) in schools is the responsibility of the guidance and conseling (BK) teachers only. In addition, there are differences in perceptions of inclusive school climate between high school and vocational school teachers, where vocational teachers have a more positive perception of school climate. There were things that could affect teachers' perceptions of the school climate, including teaching time and previous experience in interacting with students with special needs.

\section{Suggestion}

Based on the results of this study, some suggestions could be given including: under- standing and acceptance of teachers towards the implementation of inclusive schools need to be improved. This can be done through training related to the implementation of inclusive schools, for example training on creating Inclusive Learning Programs (Program Pembelajaran Inklusi) for students with special needs to the implementation and monitoring of programs. Training received by principals or certain teachers needs to be disseminated to other teachers. Harassment issues needed further investigation. The implementation of school administration in general as well as special inclusion programs in each school need to be evaluated. In addition, research on inclusive school climate involving students, parents, and other school members needs to be done, by comparing each level of education.]

\section{References}

Agustin, L. D., \& Pandia, W. S. S. (2017). Pemahaman pedagogik guru dalam mengajar anak berkebutuhan khusus di sekolah inklusi. Provitae Jurnal Psikologi Pendidikan, 6(1), 73-98.

Arta, A. (2018). Description of teacher's knowledge and attitudes to individual learning programs. IJDS: Indonesian Journal of Disability Studies, 5(2), 190-199. https://doi.org/10.21776/ ub.ijds.2018.005.02.8

Avramidis, E. (2013). Self-concept, social position and social participation of pupils with SEN in mainstream primary schools. Research Papers in Education, 28(4), 421-442. https://doi.org/10.1080/ 02671522.2012 .673006

Case, J. N. (2008). An exploratory study of school climate and student behavior in thirteen Delaware public elementary school. Delaware, University of Delaware.

Chakraborti-Ghosh, S., Orellana, K. M., \& Jones, J. (2014). A cross-cultural comparison of teachers' perspectives on inclusive education through a study abroad program in Brazil and in the us. International Journal of Special Education, 29(1), 4-13. Retrieved from https://www. researchgate.net/publication/286181331_A_crosscultural_comparison_of_teachers'_perspectives_ on_inclusive_education_through_a_study_abroad_program_in_brazil_and_in_the_us

Choate, J. S. (Ed.). (2004). Pengajaran inklusif yang sukses (4th ed.). Jakarta: Helen Keller International Indonesia - USAID Indonesia. 
Deku, P., \& Irene, V. (2017). Perspectives of teachers regarding inclusive education in Ghana. International Journal of Whole Schooling, 13(3), 39-54.

Dernowska, U. (2017). Teacher and student perceptions of school climate. Some conclusions from school culture and climate research. Journal of Modern Science, 1(32), 63-82.

Dev, S., \& Kumar, J. (2015). Teacher's perception towards integration of learning disabled students into regular class room - A study in Dubai \& Abu Dhabi schools. Procedia - Social and Behavioral Sciences, 211(November), 605-611. https://doi.org/10.1016/j.sbspro.2015.11.079

Freiberg, H. J., \& Stein, A. T. (2005). School climate. New York: Falner Press.

Friend, M. P., \& Bursuck, W. D. (2015). Including students with special needs : A practical guide for classroom teachers (7th ed.). Singapura: Pearson Education, Inc.

Irwanto, I., Kasim, E. R., Fransiska, A., Lusli, M., \& Okta, S. (2010). Analisis situasi penyandang disabilitas di Indonesia: Sebuah desk review. Depok.

Kirk, S., Gallagher, J. A., Coleman, M. R., \& Anastasiow, N. (2012). Educating exceptional children (13th ed.). Singapore: Wadsworth Cengage Learning.

MacFarlane, K., \& Woolfson, L. M. (2013). Teacher attitudes and behavior toward the inclusion of children with social, emotional and behavioral difficulties in mainstream schools: An application of the theory of planned behavior. Teaching and Teacher Education, 29(1), 46-52. https://doi.org/ 10.1016/j.tate.2012.08.006

Moran, E., Carlson, J. S., \& Tableman, B. (2012). School climate and learning. In N. M. Seel (Ed.), Encyclopedia of the Sciences of Learning (pp. 2962-2966). https://doi.org/10.1007/978-14419-1428-6_396

Na'imah, T., \& Tanireja, T. (2017). Student well-being pada remaja Jawa. Psikohumaniora: Jurnal Penelitian Psikologi, 2(1), 1. https://doi.org/10.21580/pjpp.v2i1.979

National School Climate Council. (2013). National school climate standards: Benchmarks to promote effective teaching, learning and comprehensive school improvement (pp. 1-21). pp. 1-21. Retrieved from www.schoolclimate.org

Schunk, D. H., Pintrich, P. R., \& Meece, J. L. (2008). Motivation in education: Theory, research, and applications (3rd ed.). New Jersey: Pearson Education, Inc.

Sellman, E. (2012). Creative learning for inclusion: Creative approaches to meet special needs in the classroom. New York: Routledge.

Sider, S., Maich, K, \& Morvan, J. (2017). School principals and students with special education needs: Leading inclusive schools. Canadian Journal of Education/Revue Canadienne de l'éducation, 40(2), 44-68. Retrieved from http://journals.sfu.ca/cje/index.php/cje-rce/article/view/2417

Song J. (2016). Inclusive education in Japan and Korea - Japanese and Korean teachers' self-efficacy and attitudes towards inclusive education. Journal of Research in Special Educational Needs, 16(S1), 643-648. https://doi.org/10.1111/1471-3802.12324

Spektor-Levy, O., \& Yifrach, M. (2017). If science teachers are positively inclined toward inclusive education, why is it so difficult? Research in Science Education, 49(3), 737-766. https://doi.org/ 10.1007/s11165-017-9636-0

Taylor, R., Smiley, L., \& Richard, S. (2009). Exceptional students: Preparing teachers for the 21st century. Singapura: McGraw-Hill Higher Education. 
Thomas, G., Walker, D., \& Webb, J. (1998). The making of the inclusive school. London: Routledge.

Triwulandari, A., \& Pandia, W. S. S. (2015). Sikap guru terhadap penerapan program inklusif ditinjau dari aspek guru. Jurnal Pendidikan dan Pemberdayaan Masyarakat, 2(2), 122. https://doi.org/ 10.21831/jppm.v2i2.6325

Unianu, E. M. (2012). Teachers' attitudes towards inclusive education. Procedia - Social and Behavioral Sciences, 33, 900-904. https://doi.org/10.1016/j.sbspro.2012.01.252

Vaughn, S., Bos, C. S., \& Schumm, J. S. (2011). Teaching students who are exceptional, diverse, and at risk in the general education classroom. Singapura: Pearson Education, Inc.

Wade, C., \& Tavris, C. (2008). Psychology. New Jersey: Pearson Education, Inc.

Zins, J. E., Weissberg, R. P., Wang, M. C., \& Walberg, H. J. (Eds.). (2004). Building academic success on social and emotional learning: What does the research say? New York: Teachers College Press. 
This page intentionally left blank. 